\title{
A novel subspecies-specific primer targeting the gyrase $B$ gene for the detection of Pectobacterium carotovorum subsp. brasiliense
}

\author{
TRI JOKO ${ }^{1, \boldsymbol{v}}$, ALAN SOFFAN ${ }^{1}$, MUHAMMAD SAIFUR ROHMAN ${ }^{2}$ \\ ${ }^{1}$ Department of Plant Protection, Faculty of Agriculture, Universitas Gadjah Mada. Jl. Flora, Bulaksumur, Sleman 552281, Yogyakarta, Indonesia. \\ Tel./fax.: +62-274-523926, •email: tjoko@ugm.ac.id \\ ${ }^{2}$ Department of Microbiology, Faculty of Agriculture, Universitas Gadjah Mada. Jl. Flora, Bulaksumur, Sleman 552281, Yogyakarta, Indonesia.
}

Manuscript received: 12 August 2019. Revision accepted: 26 September 2019.

\begin{abstract}
Joko T, Soffan A, Muhammad Saifur Rohman MS. 2019. A novel subspecies-specific primer targeting the gyrase B gene for the detection of Pectobacterium carotovorum subsp. brasiliense. Biodiversitas 20: 3042-3048. Pectobacterium carotovorum subsp. brasiliense is one of the major causative bacterial pathogens of the soft rot disease in various crops. It has a high virulence and a wide range of hosts in the tropics and the subtropics. Most often, conventional methods are not able to accurately distinguish $P$. carotovorum subsp. brasiliense from other subspecies. Thus, this study aimed to design a specific gyrase B gene (gyrB) -based primers for the detection and identification of soft rot pathogen. The specific primers design was based on the alignment using gyr $B$ gene sequence data from $P$. carotovorum subsp. brasiliense and other data from the GenBank. The primers comprised of F-gyr-Pcb (5'-CAC AGG CAC CGC TGG CTG TT-3') and R-gyr-Pcb (5'-CGT CGT TCC ACT GCA ATG CCA-3') with an amplicon of 336 base pairs. The specificity of the primers pair was verified both in silico and in polymerase chain reaction (PCR) assays, where the primers could only detect $P$. carotovorum subsp. brasiliense. Primers' sensitivity was determined by qualitative PCR with a detection limit of less than 0.5 $\mathrm{ng} / \mu \mathrm{L}$ of genomic DNA. Hence, the proposed detection tool can be beneficial to advance further studies on the ecology and epidemiology of soft rot diseases.
\end{abstract}

Keywords: Gyrase B, Polymerase chain reaction, Pectobacterium, Soft rot, Specific primer.

\section{INTRODUCTION}

As one of the major diseases of crops, soft rot leads to enormous losses to agriculture in different parts of the world (Perombelon and Kelman 1980; Bhat et al. 2010). In host plants, the bacterial pathogens produce massive pectolytic enzymes causing maceration and damage to the cell wall (Joko et al. 2007; 2018). Gram-negative bacteria, which belongs to the soft rot Enterobacteriaceae (SRE) group, is the causal factor of the disease (Charkowski et al. 2012), whose main causative agents belong to the genera Dickeya and Pectobacterium. The host range of these pathogens includes monocotyledonous and dicotyledonous plants (Ma et al. 2007). The level of diversity in SRE species so vary greatly that it is attributed to the unique taxon in the group (Seo et al. 2002), with a range of different phenotypic, biochemical, host range, and genetic characteristic (Toth et al. 2003). The genus Pectobacterium comprises the following species: Pectobacterium carotovorum, Pectobacterium atrosepticum, Pectobacterium betavasculorum, Pectobacterium cacticida, Pectobacterium aroidearum (Nabhan et al. 2013), Pectobacterium wasabiae, Pectobacterium parmentieri (Khayi et al. 2016), Pectobacterium polaris (Dees et al. 2017), Pectobacterium peruviense (Waleron et al. 2018), and Pectobacterium punjabense (Sarfraz et al. 2018). In addition, Pectobacterium zantedeschiae (Waleron et al. 2019a), Pectobacterium aquaticum (Pedron et al. 2019), Pectobacterium fontis (Oulghazi et al. 2019), Pectobacterium polonicum (Waleron et al. 2019b), and the new genomospecies, Candidatus Pectobacterium maceratum (Shirshikov et al. 2018; Waleron et al. 2019c) are recently added to the genus. $P$. carotovorum isolates are subsequently divided into three different subspecies viz. $P$. carotovorum subsp. carotovorum, $P$. carotovorum subsp. odoriferum, and $P$. carotovorum subsp. brasiliense (Nabhan et al. 2012a). P. carotovorum subsp. brasiliense which was first discovered in Brazil (Duarte et al. 2004), has been reported to possess a very high virulence and cause blackleg symptom in potatoes and soft rot on broader hosts such as capsicum, wild carrot (Nabhan et al. 2012b), Styrian oil pumpkin (Gottsberger and Huss 2016), Chinese cabbage, tomato, eggplant, nepenthes (Lee et al. 2014), and several other perennial plants.

It is essential that the economic loss caused by $P$. carotovorum subsp. brasiliense in plants and postharvest produce, and the limited alternatives for disease control, accurate and rapid detection techniques of the pathogen during the early stages of infection are highly considered. Using polymerase chain reaction (PCR) techniques involving the amplification of specific genes, pathogenic bacteria can be detected and identified. Such technique is considered as one of the most accurate detecting methods, compared to conventional methods or serological techniques (Windari et al. 2015; Ismiyatuningsih et al. 2016). 16S rRNA gene is one of the universal genes commonly used for bacterial identification. However, the slow evolutionary rate of this gene limits its use in differentiating closely related species (Pei et al. 2010; Poretsky et al. 2014). Meanwhile, the use of housekeeping 
genes such as the gyrase B gene $($ gyrB $)$, which is not frequently transmitted horizontally (Jain et al. 1999), evolves at a higher rate than the rRNA gene and is found in most of the bacterial species (Kasai et al. 1998). The gyrB gene has been widely used in the phylogenetic analysis of plant pathogenic bacteria such as Pantoea ananatis (Nurjanah et al. 2017), Burkholderia plantarii, B. glumae, B. gladioli (Maeda et al. 2006), and Pseudomonas aeruginosa (Lee et al. 2011). The sequence homology of the $\operatorname{gyr} B$ gene in bacteria is a suitable molecular marker for the design specific primers and is prototypical to molecular detection using PCR. This study reported a new and sensitive pair of primers for the detection of $P$. carotovorum subsp. brasiliense designed using the partial gene sequence of the gyrB gene. It encodes the subunit B protein of the DNA gyrase and a type II DNA topoisomerase (which plays an important role in DNA replication, transcription and repair, and control the level of supercoiling) that are universally distributed in bacterial species.

\section{MATERIALS AND METHODS}

\section{Bacterial strains}

Pectobacterium carotovorum subsp. brasiliense Pal3.4 which was previously isolated from orchid plant tissues (Joko et al. 2014) were routinely cultured on yeast peptone agar (YPA) medium $(0.5 \%$ yeast extract; $1 \%$ polypeptone; $1.5 \%$ agar) at $\mathrm{pH}$ 6.8. The bacterial cultures were then incubated for 1-2 days at room temperature. The bacterial strains used to test the sensitivity and specificity of primers were collected from the Laboratory of Plant Diseases, Faculty of Agriculture, Universitas Gadjah Mada, while the reference strains were obtained from Belgian Co-ordinated Collection of Micro-organisms (Table 1). To maintain viability and purity, all strains were sub-cultured on sterile YPA medium at their optimum temperatures.

\section{DNA extraction}

Bacterial DNA was isolated based on the minipreparation DNA isolation method described by Ausubel et al. (2003). A volume of $1.5 \mathrm{~mL}$ cell culture was centrifuged at $5,000 \mathrm{rpm}$ for $2 \mathrm{~min}$. The pellets were then suspended in $540 \mu \mathrm{L}$ TE buffer (0.1 M Tris-HCl, 0.1 M EDTA pH 8) and $30 \mu \mathrm{L}$ of $10 \%$ SDS was added. The mixture was incubated at $37{ }^{\circ} \mathrm{C}$ for $1 \mathrm{~h}$. Furthermore, $100 \mu \mathrm{L}$ of $5 \mathrm{M}$ $\mathrm{NaCl}$, and $80 \mu \mathrm{L} \mathrm{CTAB} / \mathrm{NaCl}(10 \% \mathrm{CTAB}$ in $0.7 \mathrm{M} \mathrm{NaCl})$ were added to the mixture, homogenized, and incubated at $65{ }^{\circ} \mathrm{C}$ for $10 \mathrm{~min}$. A volume of $750 \mu \mathrm{L}$ chloroform: isoamyl alcohol (24:1) was added, the contents of the tube were mixed by inversion and the mixture was centrifuged at $12,000 \mathrm{rpm}$ for $5 \mathrm{~min}$. The top layer was transferred to a new $1.5 \mathrm{~mL}$ Eppendorf tube and $600 \mu \mathrm{L}$ phenol: chloroform: isoamyl alcohol (25: 24:1) was added. The contents of the tube were mixed by inversion and then centrifuged at $12,000 \mathrm{rpm}$ for $5 \mathrm{~min}$. The top layer was transferred to a new Eppendorf tube and $600 \mu \mathrm{L}$ of isopropanol was added to precipitate the nucleic acids. The mixture was centrifuged at $12,000 \mathrm{rpm}$ for $5 \mathrm{~min}$. The pellets formed were washed with $70 \%$ ethanol, dried and suspended in $30 \mu \mathrm{L}$ TE buffer (Trianom et al. 2019).
Table 1. List of bacterial strains used in this study

\begin{tabular}{ll}
\hline Name of bacteria listed in collections & \multicolumn{1}{c}{$\begin{array}{c}\text { Collection and } \\
\text { number }\end{array}$} \\
\hline Pectobacterium carotovorum subsp. brasiliense & UGM/Pal3.4 \\
P. carotovorum subsp. carotovorum & UGM/Pcc-1 \\
P. carotovorum subsp. odoriferum & BCCM/LMG 17566 \\
Acidovorax citrulli & UGM/Aac-1 \\
A. avenae & BCCM/LMG 2117 \\
A. cattleyae & BCCM/LMG 2364 \\
Xanthomonas citri & UGM/Xc-07 \\
Pantoea stewartii subsp. stewartii & UGM/Pss-03 \\
Ralstonia syzygii subsp. syzygii & UGM/KD1 \\
$R$. syzygii subsp. celebesensis & UGM/BDB-05 \\
$R$ pseudosolanacearum & UGM/RS-1 \\
\hline
\end{tabular}

\section{The $\operatorname{gyr} B$ sequence determination}

The gyrB region of $P$. carotovorum subsp. brasiliense Pal3.4 was amplified using the PCR method described by Dauga (2002) with the degenerate primers gyr-320; 5'TAARTTYGAYGAYAACTCYTAYAAAGT-3' $(\mathrm{R}=\mathrm{A}$ or $\mathrm{G} ; \mathrm{Y}=\mathrm{C}$ or $\mathrm{T}$ ) and rgyr-1260; 5'CMCCYTCCACCARGTAMAGTTC-3' ( $\mathrm{M}=\mathrm{A}$ or $\mathrm{C}$ ). The reaction was done using a GoTaq Green Kit (Promega). The $25 \mu \mathrm{L}$ reaction volume contained $2.5 \mu \mathrm{L}$ of DNA template, $1.5 \mu \mathrm{L}$ of forward and reverse primer $(10$ $\mu \mathrm{M}), 12.5 \mu \mathrm{L}$ of GoTaq Green master mix and $7 \mu \mathrm{L}$ of nuclease-free water. As the initial denaturation, the tubes were placed in a PCR machine (Biorad T100, Germany) at a temperature of $94{ }^{\circ} \mathrm{C}$ for $5 \mathrm{~min}$. Gene amplification was carried out in 35 cycles, whose stages in each include: denaturation of DNA at $94{ }^{\circ} \mathrm{C}$ for $1 \mathrm{~min}$, annealing of DNA at $55^{\circ} \mathrm{C}$ for $1 \mathrm{~min}$, extension at $72{ }^{\circ} \mathrm{C}$ for $2 \mathrm{~min}$, and a final extension at $72{ }^{\circ} \mathrm{C}$ for $10 \mathrm{~min}$. DNA was sequenced by sending the PCR products to the $1^{\text {st }}$ BASE company in Malaysia (Dwimartina et al. 2017). To analyze the nucleotide sequences, Bioedit 7.1.7 program was in use (Hall 1999).

\section{Design of specific gyrB -based primers}

The primers design was based on the low conservation level between the gyrB genes from $P$. carotovorum subsp. brasiliense Pal3.4 and other closely related bacteria. The DNA sequence of the gyrB gene from $P$. carotovorum subsp. carotovorum LMG 2404T (JF311601), $P$. carotovorum subsp. odoriferum LMG 17566T (KJ818409), $P$. atrosepticum LMG 2386T (JF311589), P. wasabiae LMG 8444 (JF311608), P. betavasculorum LMG 2466T (JF311593), and P. cacticida LMG 17936T (JF311597) were retrieved from the GenBank Nucleotide database and harmonized using the Multalin program (http://multalin. toulouse.inra.fr/multalin/cgi-bin/multalin.pl). nucleotides were picked up from the unique and low conservation base sequence region selected in $P$. carotovorum subsp. brasiliense. The base sequence was different from that in other species of Pectobacterium spp. Later on, analysis of forward and reverse primers for this analysis took place. During the design of primers, melting temperature (Tm), GC content, dimer potential (the ability of the PCR primers to anneal to each other) and hairpin 
loop formation (Trianom et al. 2018) came into consideration. These properties were determined by an oligocalculator (Kibbe 2007), accessed via http://www.basic.northwestern.edu/biotools/oligocalc.html. Furthermore, in silico specificity of forward and reverse primers was analyzed using NCBI BLASTN. The selected primers were synthesized through Integrated DNA Technology (IDT, Singapore) services.

\section{Polymerase chain reaction and primer optimization}

PCR was performed using a selected specific primer. The reaction involved the use of master mix GoTaq Green (Promega), with a composition of $12.5 \mu \mathrm{L}$ Master mix, 1.5 $\mu \mathrm{L}$ of forward and reverse primer $(10 \mu \mathrm{M}), 2.5 \mu \mathrm{L}$ of DNA template and $7 \mu \mathrm{L}$ of nuclease-free water. The reaction was done in PCR machine (Biorad T100, Germany) at $94{ }^{\circ} \mathrm{C}$ for 5 min for initial denaturation, followed by 35 cycles amplification. The annealing temperature was optimized using gradient PCR by carrying out the reaction at the following temperatures: $65^{\circ} \mathrm{C}, 64.7{ }^{\circ} \mathrm{C}, 64.2^{\circ} \mathrm{C}, 63.5^{\circ} \mathrm{C}$, $62.5^{\circ} \mathrm{C}, 61.8^{\circ} \mathrm{C}, 61.3^{\circ} \mathrm{C}$ and $61.0^{\circ} \mathrm{C}$ (Widyaningsih et al. 2019). To carry out the standard process of PCR, an extension at $72{ }^{\circ} \mathrm{C}$ for $2 \mathrm{~min}$ and final extension at $72{ }^{\circ} \mathrm{C}$ for $10 \mathrm{~min}$ were in use. Adequate number of cycles was determined in manual manner and the products of the reaction were maintained at $4{ }^{\circ} \mathrm{C}$.

The amplification results (DNA fragments) were analyzed using gel electrophoresis, comprising $1 \%$ agarose gel in $1 \times$ TBE buffer (Tris/Borate/EDTA: $89 \mathrm{mM}$ Tris, 89 $\mathrm{mM}$ boric acid, $2 \mathrm{mM}$ EDTA, $\mathrm{pH} 8.3$ ) at 50 volts of DC voltage for $50 \mathrm{~min}$. To measure the size of the DNA fragments, a DNA ladder (Promega) of 100-bp marker was used. The sample was prepared by mixing $5 \mu \mathrm{L}$ of DNA with $2 \mu \mathrm{L}$ of $1 \%$ gel red (Biotium). After electrophoresis, the gel was visualized under UV $(300 \mathrm{~nm})$ illumination (Mahfut et al. 2016; Sutrisno et al. 2018).

\section{Specificity and sensitivity of the PCRs}

For the amplification of the predicted size fragment, specificity, and sensitivity, the primers pair of F-gyrPcb/R-gyr-Pcb was tested. The primers' specificity in the detection of $P$. carotovorum subsp. brasiliense was determined using the following bacterial species: $P$. carotovorum subsp. carotovorum Pcc-1, P. carotovorum subsp. odoriferum LMG 17566, Acidovorax citrulli Aac-1, Acidovorax avenae LMG 2117, Acidovorax cattleyae LMG 2364, Xanthomonas citri Xc-07, Pantoea stewartii subsp. stewartii Pss-03, Ralstonia syzygii subsp. syzygii KD1, Ralstonia syzygii subsp. celebesensis BDB-05, and Ralstonia pseudosolanacearum RS-1. The specificity tests of the PCR experiments were repeated twice for the assessment of technological reproducibility and stability.

In the purpose of determining how the primer sensitivity influenced the detection of the target bacterial DNA using DNA controls, the sensitivity of the PCRs were evaluated. The assays were carried out using a series of dilutions, which included control DNA (DNA suspension without dilution), and $10 \times, 50 \times, 100 \times, 500 \times, 1000 \times$, and
$10,000 \times$ dilutions. Measuring the concentration of the control DNA (i.e. the purity) was performed using spectrophotometer (Genesys 10S UV-vis, Thermo Scientific) for the optical density ratio of $\mathrm{OD}_{260} / \mathrm{OD}_{280}$ (Joko et al. 2012). The amplified products were subjected to electrophoresis on $1 \%$ agarose gel and visualized under UV $(300 \mathrm{~nm})$ illumination.

\section{RESULTS AND DISCUSSION}

\section{Sequence analysis of $g y r B$ gene and selection of primers pair}

Approximately $1 \mathrm{~kb}$ amplicon was observed by PCR with the universal primers of gyr-320 and rgyr-1260 from $P$. carotovorum subsp. brasiliense Pal3.4 bacterial isolate. The edited nucleotide sequences of the PCR product were determined and deposited in GenBank under the accession number MK358121. These partial gyrB sequences were then aligned with the $g y r B$ database of the closely related species ( $P$. carotovorum subsp. carotovorum, $P$. carotovorum subsp. odoriferum, $P$. atrosepticum, $P$. wasabiae, $P$. betavasculorum, $P$. cacticida) retrieved from the GenBank. The results of the bacterial alignment showed high similarities in the respective DNA sequences; $P$. carotovorum subsp. carotovorum and $P$. carotovorum subsp. odoriferum were detected with the highest conservation level at $94.7 \%$ and $94.5 \%$, respectively. Specific primers for $P$. carotovorum subsp. brasiliense were determined based on the sequence region with low conservation; especially with those belonging to $P$. carotovorum subsp. carotovorum and $P$. carotovorum subsp. odoriferum.

According to Frank et al. (2008), among the various regions in a gene sequence (i.e. the phylogeny group reflecting the genetic variation across species), the conserved region is commonly used as the universal PCR primer, while the variable region posing a unique sequence profile can be utilized as the specific primer. Therefore, selecting and focusing on the relatively high heterogeneity of gyrB sequence regions within $P$. carotovorum subspecies were essential for the successful design of a specific primer of $P$. carotovorum subsp. brasilense. Multiple sequence alignments of the $g y r B$ genes of all Pectobacterium species revealed enough variations used to design subspecies-specific primer pairs of $P$. carotovorum subsp. brasilense. A pair with a base sequence of 5'-CAC AGG CAC CGC TGG CTG TT-3' and 5'-CGT CGT TCC ACT GCA ATG CCA-3' was the successfully designed primer based on the alignment of $g y r B$ sequences. This primer is called F-gyr-Pcb (forward) and R-gyr-Pcb (reverse). The binding positions of the primers are starting at base number 456 (forward) and 797 (reverse) relative to the full-length of gyrB gene sequence from $P$. carotovorum subsp. brasilense type strain LMG $21371^{\mathrm{T}}$ with accession number JQOE01000006 and locus tag KS44_15300 (Figure 1). 
1 ATGTCGAATTCTTATGACTCCTCAAGTATCAAGGTATTGAAAGGGCTGGATGCGGTACG

61 TAAACGCCCAGGTATGTATATCGGCGATACGGACGACGGTACCGGCCTGCATCACATGG

121 TATTCGAGGTTGTGGACAACGCTATCGACGAAGCACTCGCTGGCTATTGTAAAGACATT

181 ATCATCACCATCCATGCTGATAACTCGGTATCGGTGCAGGATGATGGTCGTGGTATTCC

241 GACTGGCATTCACGAAGAAGAAGGTATCTCCGCGGCTGAAGTCATCATGACCGTGCTGC

301 ACGCGGGCGGTAAGTTCGATGATAACTCGTATAAAGTTTCTGGCGGCTTGCACGGCGTA

361 GGGGTTTCCGTGGTTAACGCCCTGTCGGAAAAACTGACGCTGGTTATCCACCGCGACGG

GAAACTTCACGAGCAAACCTATAAACACGGCGTGGCACAGGCACCGCTGGCTGTTACGG

541 AACGTGGTGGAATTCGAGTATGAGATTCTGGCCAAGCGTCTGCGCGAGCTGTCGTTCCT

601 GAACTCCGGTGTCTCCATCCGCTTGATCGACGAGCGTGAGAAAGATAAAGCCGATCATT

661 ACCATTATGACGGCGGCATCAAGGCGTTTGTTGATTACCTGAACCGTAACAAGACGCCA

721 ATTCACCCGAACGTGTTTTATTTCTCGACGGTGAAAGATGATATCGGCGTGGAAG TGGC

781 ATTGCAGTGGAACGACGGTTTCCAGGAAAACATTTACTGCTTTACCAACAACATTCCAC R-gyr-Pcb $\longleftarrow$

841 AGCGCGACGGTGGTACGCACTTGGCCGGTTTCCGTGCCGCGATGACCCGTACGCTGAA T

901 ACCTACATGGATAAAGAAGGCTACAGCAAGAAAGCCAAAGTCAGCGCCACCGGTGACGA

961 TGCGCGTGAAGGGCTGATTGCCGTGGTTTCCGTGAAAGTGCCGGATCCGAAATTCTCCT

1021 CGCAGACCAAAGACAAGCTGGTTTCTTCCGAAGTGAAAACGGCGGTTGAATCGCTGATG

1081 AACGAGAAGCTGGTGGACTATCTGATGGAAAACCCATCGGATGCCAAAATCGTGGTCGG

1141 TAAAATTATTGATGCCGCACGTGCCCGTGAAGCGGCGCGTAAAGCGCGTGATATGACGC

1201 GTCGTAAAGGTGCGCTCGATCTGGCTGGCCTGCCGGGCAAACTGGCAGATTGT CAGGAA

1261 CGAGACCCCGCGCTGTCTGAACTGTACCTGGTGGAAGGGGACTCAGCGGGCGGCTCTGC

1321 TAAGCAGGGGCGTAACCGTAAGAACCAGGCGATTCTGCCGCTGAAGGGTAAAATCCTGA

1381 ACGTTGAGAAAGCGCGTTTTGACAAGATGCTTTCCTCGCAGGAAGTCGCGACGCTGATC

1441 ACCGCGCTGGGCTGCGGCATTGGCCGTGATGAATACAACCCGGACAAACTGCGCTACCA

1501 CAACATCATCATCATGACCGATGCTGACGTGGATGGTTCGCACATCCGTACTCTGCTGT

1561 TGACCTTCTTCTATCGTCAACTGCCTGAAATCGTTGAGCGTGGTCACGTGTATATTGCT

1621 CAGCCGCCGCTGTACAAGGTGAAAAAAGGCAAGCAGGAACAGTACATCAAAGATGATGA

1681 AGCGATGGATCAGTACCAGATCGCACTGGCGCTAGACGGCGCGACGCTGCACACCAATG

1741 CACAGGCTCCTGCGCTGGCGGGTGAACCGCTGGA GAAACTGGTTTCTGAACATTACGCC

1801 GTACAGAAGATGATTGGCCGCATGGAACGTCGCTTCCCACGTGTGTTCTTGAACCGCCT

1861 GATCTATCAACCAACGTTGGCTGAAGCCGATTTGGGCGAGCGTGAAAAAGTACAGGCGT

1921 GGGCGGAATCGCTGGTTAGCAGCCTGAACGAAAACGAGATTCACGGCAGCACATACAGT

1981 TTTGTCATTCATCATGATGAAGAGCGCAGCGTATTTGAACCCGCGCTGCGCGTGCGTAC

2041 GCACGGTGTGGATACCGATTATCCGCTGGGCGCAGGCTTCGTGGCGGGTAGCGAATACC

2101 GCAAATTGAATCAGCTGGGTGAAAAACTGCGCGGCCTGATTGAAGAAGATGCGTACATT

2161 GAACGTGGTGAGCGTCGTCAACCGGTTGCCAGCTTTGAACAGGCGCTGGAGTGGCTGGT

2221 GAAAGAATCCCGCCGTGGTCTGACCGTACAGCGCTATAAAGGTCTGGGTGAAATGAACC

2281 CGGATCAGCTGTGGGAAACCACGATGGATCCGACTAGCCGCCGCATGCTGCGCGTGACG

2341 GTGAAAGACGCCATCGCCGCTGATGAGCTGTTCACGACGCTGATGGGTGATGCGGTTGA

2401 ACCACGCCGTGCATTTATCGAAGAGAACGCCCTGAAAGCGATGAATATCGATATCTGA

Figure 1. Annealing positions of primers F-gyr-Pcb/R-gyr-Pcb in the full-length of gyrB sequence from Pectobacterium carotovorum subsp. brasiliense LMG $21371^{\mathrm{T}}$ (type strain). The sequence of the primers designed are underlined and indicated by arrows

The primers' characteristics of F-gyr-Pcb/R-gyr-Pcb include GC content: $65 \%$ (F-gyr-pcb) and 57\% (R-gyr$\mathrm{Pcb})$, melting temperature $(\mathrm{Tm}): 58^{\circ} \mathrm{C}(\mathrm{F}-\mathrm{gyr}-\mathrm{Pcb})$ and 56 ${ }^{\circ} \mathrm{C}$ (R-gyr-Pcb), absence of secondary structures (hairpindimer) and complementary region. These properties indicated that the primers can be used as a specific candidate that is ideal for detecting the target genes (Dieffenbach et al. 1993). Searching the NCBI database by submitting the primer strings separately was the form of evaluating in silico primers' pair specificity. The BLAST search with the 20-bp string of primer F-gyr-Pcb and 21-bp string of primer R-gyr-Pcb as the query was retrieved as it was the most similar one to the published sequences of the $P$. carotovorum subsp. brasiliense strains. It was found that the two primers had $100 \%$ specificity toward $P$. carotovorum subsp. brasiliense and less than $91 \%$ similarity to closely related bacteria (Table 2). Except for the expected target sequences, no other BLAST results were common to both searches, confirming the specificity of the primers' pair.

\section{PCR optimization with specific primers}

Amplification was carried out using the specific primers (F-gyr-Pcb/R-gyr-Pcb) developed from the gyrase B genes. These specific primers facilitated the detection of $P$. carotovorum subsp. brasiliense with an amplicon length of 336-bp (Figure 2). Annealing temperatures may influence PCR specificity. The lower annealing temperatures and additional PCR amplification cycles may lead to nonspecific PCR products. In this study, the most appropriate annealing temperature for F-gyr-Pcb/R-gyr-Pcb primers was found at $61{ }^{\circ} \mathrm{C}$, with 35 cycles of PCR amplification as 
indicated from the clear single band of the expected size visualized from ethidium bromide gel. Other PCR conditions supporting the best amplification included the initial denaturation at $94^{\circ} \mathrm{C}$ for $5 \mathrm{~min}$, the amplification process of 35 cycles comprising the denaturation process at $94^{\circ} \mathrm{C}$ for $1 \mathrm{~min}$, the annealing process at $61^{\circ} \mathrm{C}$ for $1 \mathrm{~min}$, and elongation process at $72^{\circ} \mathrm{C}$ for $2 \mathrm{~min}$. The standard PCR process was then carried out with the extension at $72^{\circ} \mathrm{C}$ for $2 \mathrm{~min}$, followed by a final elongation step at $72^{\circ} \mathrm{C}$ for $10 \mathrm{~min}$. The consistency of the PCR program was analyzed using a different PCR machine from different manufacturers generating consistent results to infer the reproducibility of the PCR process (data not shown).

Table 2. Level of similarity of forward and reverse primers aligned with gyrB sequences of other Pectobacterium spp. retrieved from GenBank.

\begin{tabular}{|c|c|c|}
\hline Primer & $\begin{array}{l}\text { Simi- } \\
\text { larity } \\
(\%)\end{array}$ & Reference strains \\
\hline F-gyr- & 89.5 & P. betavasculorum LMG 2466T \\
\hline \multirow[t]{6}{*}{$\mathrm{Pcb}$} & 87.5 & P. cacticida LMG $17936 \mathrm{~T}$ \\
\hline & 84.2 & P. wasabiae LMG 8444 \\
\hline & 89.5 & P. atrosepticum LMG $2386 \mathrm{~T}$ \\
\hline & 85.0 & P. carotovorum subsp. carotovorum LMG $2404 \mathrm{~T}$ \\
\hline & 85.0 & P. carotovorum subsp. odoriferum LMG $17566 \mathrm{~T}$ \\
\hline & 100 & P. carotovorum subsp. brasiliense LMG 21370 \\
\hline R-gyr- & 90.5 & P. betavasculorum LMG $2466 \mathrm{~T}$ \\
\hline \multirow[t]{6}{*}{ Pcb } & 85.7 & P. cacticida LMG $17936 \mathrm{~T}$ \\
\hline & 90.5 & P. wasabiae LMG 8444 \\
\hline & 90.5 & P. atrosepticum LMG $2386 \mathrm{~T}$ \\
\hline & 85.7 & P. carotovorum subsp. carotovorum LMG $2404 \mathrm{~T}$ \\
\hline & 90.5 & P. carotovorum subsp. odoriferum LMG $17566 \mathrm{~T}$ \\
\hline & 100 & P. carotovorum subsp. brasiliense LMG 21370 \\
\hline
\end{tabular}

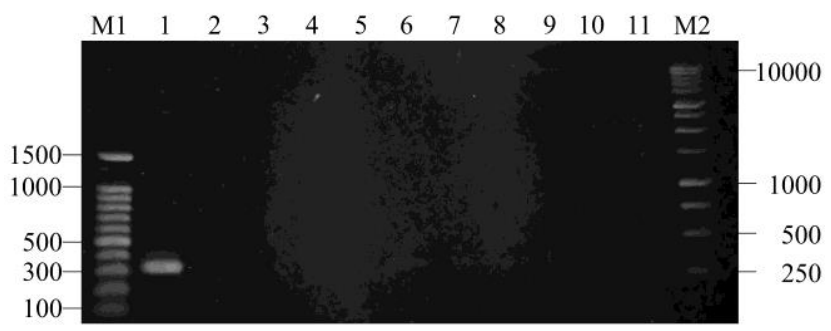

Figure 2. PCR amplification of bacterial strain DNA using Pectobacterium carotovorum subsp. brasiliense specific (F-gyr$\mathrm{Pcb} / \mathrm{R}-\mathrm{gyr}-\mathrm{Pcb}$ ) primers. $\mathrm{PCR}$ products were resolved by $1 \%$ agarose gel electrophoresis. Lane 1, P. carotovorum subsp. brasiliense Pal3.4; lane 2, P. carotovorum subsp. carotovorum Pcc-1; lane 3, P. carotovorum subsp. odoriferum LMG 17566; lane 4, Acidovorax citrulli Aac-1; lane 5, Acidovorax avenae LMG 2117; lane 6, Acidovorax cattleyae LMG 2364; lane 7, Xanthomonas citri Xc-07; lane 8, Pantoea stewartii subsp. stewartii Pss-03; lane 9, Ralstonia syzygii subsp. syzygii KD1; lane 10, Ralstonia syzygii subsp. celebesensis BDB-05; lane 11, Ralstonia pseudosolanacearum RS-1.

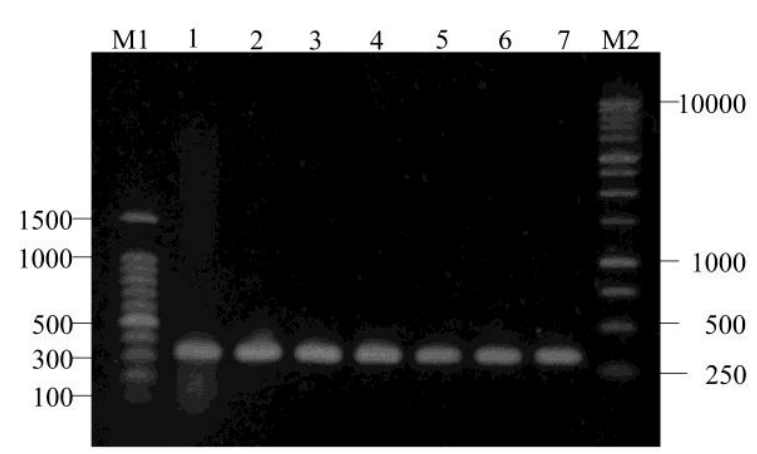

Figure 3. Sensitivity of the F-gyr-Pcb/R-gyr-Pcb primers against serially diluted genomic DNA samples of Pectobacterium carotovorum subsp. brasiliense. Lanes M1/M2: 100-bp/1-kb ladder (Promega). Lanes 1-7: $5 \times 10^{3}, 5 \times 10^{2}, 10^{2}, 5 \times 10^{1}, 10^{1}$, $5 \times 10^{-1}, 5 \times 10^{-2} \mathrm{ng}$

\section{PCR assay for primer specificity and sensitivity}

The specificity of primers F-gyr-Br/R-gyr-Br was evaluated against the extracted DNA from the target and tested bacterial strains. The results indicated that the primers were highly specific for amplifying genomic DNA from $P$. carotovorum subsp. brasiliense. The single amplicon with the expected size (336-bp) of the target gene was formed consistently in all cases of PCR reaction. Meanwhile, for the non-target gene (other than $P$. carotovorum subsp. brasiliense), the amplicon did not form during the PCR reactions. The generation of a single band of the expected size exclusively in the target genome sample ( $P$. carotovorum subsp. brasiliense) indicated that the designed primers pair was successfully hybridized to the template of DNA molecules and proved to be specific (Van Pelt-Verkuit et al. 2008).

Conducting a set of tests with DNA template dilution proportional to the DNA concentration value (qualitative PCR) was done to observe primers sensitivity qualitatively. This result was apparently the same as the visualization of the DNA intensity in Figure 3. The greater the DNA dilution, the smaller the DNA intensity in the electrophoresis gel. DNA concentrations with dilutions of up to $10,000 \times$ (concentrations of $0.5 \mathrm{ng} / \mathrm{L}$ ) could still be amplified with the F-gyr-Pcb/R-gyr-Pcb primers. This implies that it is sensitive enough that PCR is using this pair of primers to detect $P$. carotovorum subsp. brasiliense. These experiments substantiate the threshold level of qualitative PCR for detecting the amplification signal. The prevailing uncertainty in the identification of $P$. carotovorum subsp. brasiliense may be reduced due to the development of subspecies-specific primers. Kim et al. (2013) reported that the sensitivity of $g y r B$-based primers was much higher than in the identification using conventional microbiology-based culture. Therefore, the primers that are specifically designed may overcome the commonly occurring problem of subspecies detection. Such subspecies detection majorly exists in the culturedependent methods which become problematic in relatively lower amounts of bacterial load. The gyrB target gene appears to be an ideal molecular marker for the accurate discrimination and identification by making use of a 
subspecies-specific PCR assay followed by direct sequencing. Application of PCR-based methods, combined with population genetic studies may help unravel the biological plasticity of $P$. carotovorum subsp. brasiliense, which then leads to a deeper understanding of the environmental risk associated with large-scale distribution of the bacterial pathogen.

\section{ACKNOWLEDGEMENTS}

The authors would like to express their deep gratitude to the Ministry of Research, Technology and Higher Education (KEMENRISTEKDIKTI) of the Republic of Indonesia for funding this research through the PDUPT 2018 budget (contract number 202/UN1/DITLIT/DITLIT/LT/2018).

\section{REFERENCES}

Ausubel FM, Brent R, Kingston RE, Moore DD, Seidman JG, Smith JA Struhl K. 2003. Current protocols in molecular biology. John Wiley \& Sons Inc., New York.

Bhat KA, Masood SD, Bhat NA, Bhat MA, Razvi SM, Mir MR, Akhtar S, Wani N, Habib M. 2010. Current status of postharvest soft rot in vegetables: A review. Asian J Plant Sci 9: 200-208.

Charkowski A, Blanco C, Condemine G, Expert D, Franza T, Hayes C, Hugouvieux-Cotte-Pattat N, Solanilla EL, Low D, Moleleki L, Pirhonen M, Pitman A, Perna N, Reverchon S, Palenzuela PR, San Francisco M, Toth I, Tsuyumu S, van der Waals J, van der Wolf J, Van Gijsegem F, Yang CH, Yedidia I. 2012. The role of secretion systems and small molecules in soft-rot Enterobacteriaceae pathogenicity. Ann Rev Phytopathol 50: 425-429.

Dauga C. 2002. Evolution of the gyrB gene and the molecular phylogeny of Enterobacteriaceae: a model molecule for molecular systematic studies. Intl J Syst Evol Microbiol 52: 531-547.

Dees MW, Lysøe E, Rossmann S, Perminow J, Brurberg MP. 2017. Pectobacterium polaris sp. nov., isolated from potato (Solanum tuberosum). Intl J Syst Evol Microbiol 67: 5222-5229.

Dieffenbach CW, Lowe TM, Dveksler GS. 1993. General concepts for PCR primer design. Genome Research 3: S30-S37.

Duarte V, De Boer SH, Ward LJ, De Oliveira AMR. 2004. Characterization of atypical Erwinia carotovora strains causing blackleg of potato in Brazil. J Appl Microbiol 96: 535-545.

Dwimartina F, Arwiyanto T, Joko T. 2017. Potential of endophytic and rhizobacteria as an effective biocontrol for Ralstonia syzygii subsp. syzygii. Asian J Plant Pathol 11: 191-198.

Frank JA, Reich CL, Sharma S, Weisbaum JS, Wilson BA, Olsen GJ. 2008. Critical evaluation of two primers commonly uses for amplification of bacterial 16S rRNA Genes. Appl EnvironMicrobiol 74: 2461-2470.

Gottsberger RA, Huss H. 2016. Pectobacterium carotovorum subsp. brasiliensis causing a soft rot on Styrian oil pumpkin in Austria. New Dis Rep 33: 12.

Hall TA. 1999. Bioedit: A user-friendly biological sequence alignment editor and analysis program for Windows 95/98/NT. Nucleic Acid Symp Ser 41: 95-98.

Ismiyatuningsih, Joko T, Hartono S. 2016. Survey and detection of Pectobacterium atrosepticum in major potato-growing areas in Central Java province, Indonesia. Ilmu Pertanian 1: 1-6. [Indonesian]

Jain R, Rivera MC, Lake JA. 1999. Horizontal gene transfer among genomes: The complexity hypothesis. Proc Natl Acad Sci USA 96 3801-3806.

Joko T, Hirata H, Tsuyumu S. 2007. A sugar transporter (MfsX) is also required by Dickeya dadantii 3937 for in planta fitness. J General Plant Pathol 73: 274-280.

Joko T, Koentjoro MP, Somowiyarjo S, Rohman MS, Liana A, Ogawa N. 2012. Response of rhizobacterial communities in watermelon to infection with cucumber green mottle mosaic virus as revealed by cultivation-dependent RISA. Arch Phytopathol Plant Protect 45: 1810-1818.

Joko T, Subandi A, Kusumandari N, Wibowo A, Priyatmojo A. 2014. Activities of plant cell wall-degrading enzymes by bacterial soft rot of orchid. Arch Phytopathol Plant Protect 47: 1239-1250.

Joko T, Umehara M, Murata T, Etoh H, Izumori K, Tsuyumu S. 2018. Hyperinduction of pectate lyase in Dickeya chrysanthemi EC16 by plant-derived sugars. J Plant Interact 13: 141-150.

Kasai H, Watanabe K, Gasteiger E, Bairoch A, Isono K, Yamamoto S, Harayama S. 1998. Construction of the $g y r B$ database for the identification and classification of bacteria. Proceeding of International Conference on Genomic Informatics. P. 13-21.

Khayi S, Cigna J, Chong TM, Quetu-Laurent A, Chan K, Helias V, Faure D. 2016. Transfer of the potato plant isolates of Pectobacterium wasabiae to Pectobacterium parmentieri sp. nov. Intl J Syst Evol Microbiol 66: 5379-5383.

Kibbe WA. 2007. OligoCalc: an online oligonucleotide properties calculator. Nucleic Acids Res 35: W43-W46.

Kim W, Park HK, Hwang, WJ, Shin HS. 2013. Simultaneous detection of Streptococcus pneumoniae, $S$. mitis, and $S$. oralis by a novel multiplex PCR assay targeting the gyrB Gene. J Clin Microbiol 51: 835-840.

Lee CS, Wetzel K, Buckley T, Wozniak D, Lee J. 2011. Rapid and sensitive detection of Pseudomonas aeruginosa in chlorinated water and aerosols targeting gyrB gene using real-time PCR. J Appl Microbiol 111: 893-903.

Lee DH, Kim JB, Lim JA, Han SW, Heu S. 2014. Genetic diversity of Pectobacterium carotovorum subsp. brasiliensis isolated in Korea. Plant Pathol J 30: 117-124.

Ma B, Hibbing ME, Kim HS, Reedy RM, Yedidia I, Breuer J, Glasner JD, Perna NT, Kelman A, Charkowski AO. 2007. Host range and molecular phylogenies of the soft rot enterobacterial genera Pectobacterium and Dickeya. Phytopathology 97: 1150-1163.

Maeda Y, Shinohara H, Kiba A, Ohnishi K, Furuya N, Kawamura Y, Ezaki T, Vandamme P, Tsushima S, Hikichi Y. 2006. Phylogenetic study and multiplex PCR-based detection of Burkholderia plantarii, Burkholderia glumae and Burkholderia gladioli using gyrB and $r p o D$ sequences. Intl J Syst Evol Microbiol 56: 1031-1038.

Mahfut, Joko T, Daryono BS. 2016. Molecular characterization of odontoglossum ring spot virus (ORSV) in Java and Bali, Indonesia. Asian J Plant Pathol 10: 9-14.

Nabhan S, Boer SH, Maiss E, Wydra K. 2012a. Taxonomic relatedness between Pectobacterium carotovorum subsp. carotovorum, Pectobacterium carotovorum subsp. odoriferum and Pectobacterium carotovorum subsp. brasiliense subsp. nov. J Appl Microbiol 113: 904-13.

Nabhan S, Wydra K, Linde M, Debener T. 2012b. The use of two complementary DNA assays, AFLP and MLSA, for epidemic and phylogenetic studies of pectolytic enterobacterial strains with focus on the heterogeneous species Pectobacterium carotovorum. Plant Pathol 61: 498-508.

Nabhan S, De Boer SH, Maiss E, Wydra K. 2013. Pectobacterium aroidearum sp. nov., a soft rot pathogen with preference for monocotyledonous plants. Intl J Syst Evol Microbiol 63: 2520-2525.

Nurjanah N, Joko T, Subandiyah S. 2017. Characterization of Pantoea ananatis isolated from garlic and shallot. Jurnal Perlindungan Tanaman Indonesia 21: 120-126.

Oulghazi S, Cigna J, Lau YY, Moumni M, Chan KG, Faure D. 2019. Transfer of the waterfall source isolates Pectobacterium carotovorum M022 to Pectobacterium fontis sp. nov., a deep-branching species within the genus Pectobacterium. Intl J Syst Evol Microbiol 69: 470475.

Perombelon MCM, Kelman A. 1980. Ecology of the soft rot erwinias. Ann Rev Phytopathol 18: 361-387.

Pei YA, Oberdorf WE, Nossa CW, Agarwal A, Chokshi P, Gerz AA, Jin Z, Lee P, Yang L, Poles M, Brown SM, Sotero S, De Santis T, Brodie E, Nelson K, Pei Z. 2010. Diversity of 16S rRNA genes with individual prokaryotic genomes. Appl Environ Microbiol 76: 38863897.

Pédron J, Bertrand C, Taghouti G, Portier P, Barny MA. 2019. Pectobacterium aquaticum sp. nov., isolated from waterways. Intl $\mathbf{J}$ Syst Evol Microbiol 69: 745-751.

Poretsky R, Rodriguez RLM, Luo C, Tsementzi D, Konstantinidis KT. 2014. Strengths and limitations of $16 \mathrm{~S}$ rRNA gene amplicon sequencing in revealing temporal microbial community dynamics. PLoS ONE 9: e93827. DOI: 10.1371/journal.pone.0093827. 
Sarfraz S, Riaz K, Oulghazi S, Cigna J, Sahi ST, Khan SH, Faure D. 2018 Pectobacterium punjabense sp. nov., isolated from blackleg symptoms of potato plants in Pakistan. Intl J Syst Evol Microbiol 68: 3551-3556.

Seo ST, Furuya N, Lim CK, Takanami Y, Tsuchiya K. 2002. Phenotypic and genomic diversity of Erwinia carotovora subsp. carotovora strains from Asia. J Phytopathol 150: 120-127.

Shirshikov FV, Korzhenkov AA, Miroshnikov KK, Kabanova AP, Barannik AP, Ignatov AN, Miroshnikov KA. 2018. Draft genome sequences of new genomospecies "Candidatus Pectobacterium maceratum" strains, which cause soft rot in plants. Genome Announcement 6: e00260-18. DOI: 10.1128/genomeA.00260-18.

Sutrisno, Susanto F A, Wijayanti P, Retnoningrum MD, Nuringtyas TR, Joko T, Purwestri YA. 2018. Screening of resistant Indonesian black rice cultivars against bacterial leaf blight. Euphytica 214: 199. DOI: 10.1007/s10681-018-2279-z.

Toth IK, Bell KS, Holeva MC, Birch PRJ. 2003. Soft rot erwiniae: from genes to genomes. Mol Plant Pathol 4: 17-30.

Trianom B, Arwiyanto T, Joko T. 2018. Development of novel subspecies-specific primers based on the endoglucanase gene for detection of Ralstonia syzygii subsp. syzygii. Jurnal Perlindungan Tanaman Indonesia 22: 124-131.

Trianom B, Arwiyanto T, Joko T. 2019. Morphological and molecular characterization of Sumatra disease of clove in Central Java, Indonesia. Tropical Life Sci Res 30: 107-118.
Van Pelt-Verkuit E, Van Belkum A, Hays JP. 2008. Principals and technical aspects of PCR amplification. Springer, Netherland.

Waleron M, Misztak A, Waleron M, Franczuk M, Wielgomas B, Waleron. 2018. Transfer of Pectobacterium carotovorum subsp. carotovorum strains isolated from potatoes grown at high altitudes to Pectobacterium peruviense sp. nov. Syste Appl Microbiol 41: 85-93.

Waleron M, Miztak A, Waleron M, Franczuk M, Jonca J, Wielgomas B, Mikiciński A, Popović T, Waleron K. 2019a. Pectobacterium zantedeschiae sp. nov. a new species of a soft rot pathogen isolated from Calla lily (Zantedeschia spp.). Syst Appl Microbiol 42: 275-283.

Waleron M, Misztak A, Waleron M, Jonca J, Furmaniak M, Waleron K. 2019b. Pectobacterium polonicum sp. nov. isolated from vegetable fields Intl J Syst Evol Microbiol 69: 1751-1759.

Waleron M, Miztak A, Jonca J, Furmaniak M, Waleron MM, Waleron K. 2019c. First report of 'Candidatus Pectobacterium maceratum' causing soft rot of potato in Poland. Plant Dis 103(6). DOI: 10.1094/PDIS-11-18-2107-PDN.

Widyaningsih S, Utami SNH, Joko T, Subandiyah S. 2019. Plant response and huanglongbing disease development against heat treatments on 'Siam Purworejo' (Citrus nobilis (Lour)) and 'Nambangan' $(C$. maxima (Burm.) Merr.) under field condition. Arch Phytopathol Plant Protect 52: 259-276.

Windari U, Joko T, Subandiyah S. 2015. Detection of bacterial fruit blotch of melon using ELISA. Jurnal Perlindungan Tanaman Indonesia 19: $1-5$. 